\title{
Testing the Existence of Wagner Law and Government Expenditure Volatility in Indonesia Post-Reformation Era
}

\author{
Yudistira Hendra Permana ${ }^{1}$, Gek Shinta Mas Jasmin Wika ${ }^{2}$ \\ 1. Vocational School of Economics, Universitas Gadjah Mada, Yogyakarta, 55281, Indonesia \\ 2. Faculty of Entrepreneurial Business, Universitas Ciputra, Surabaya, 60219, Indonesia \\ * E-mail of the corresponding author: yudistira_hp@yahoo.com
}

\begin{abstract}
Aim of this study is to identify the existence of Wagner's Law in Indonesia economy during post-reformation era. This study takes period sample of five regimes during 1999 - 2011, which are following: a) Development Reformation Regime; b) National Unity Regime; c) Mutual Cooperation Regime; d) Indonesia Unite I Regime; e) Indonesia Unite II Regime. In order to test the existence of Wagner's Law, we also elaborate exogenous variable (tax revenue and population) as variable control. We find the result that Wagner Law did occur in postreformation era by performing an ARDL co-integration model, yet volatility of government expenditure has to be captured. Hence, we run a GARCH model to estimate the volatility of government expenditure by elaborating the regime variable. The ARDL approach, causality test and co-integration test also support the existing of Wagner Law in this study
\end{abstract}

Keywords: Co-integration, GARCH, Wagner Law, post-reformation regimes

\section{Introduction}

Role of the government is always regarded to be important for economy growth as the government plays role on the fiscal policy. In the $19^{\text {th }}$ century, fiscal policy, especially for government expenditure, was under classical economics though which had not a significant impact to economy. It was Adolph Wagner (1883) that proposed the relationship between economic growth and government expenditure, yet to be known as Wagner Law later. $\mathrm{He}$ assumed that economic growth would boost the government expenditure relatively.

The Wagner Law then had become a debatable theory in economics after Keynesian emerged in 1930s. ${ }^{1}$ Both theories give a different explanation of the relationship between government expenditure and economic growth. Nevertheless, it is totally understandable since every country has its own behaviour on the implementation of fiscal policy and dominant factor for economic growth (Peacock \& Wiseman, 1961). It is also considerably because of no convention against causality of those factors (Wijayanti, 2008).

Specifically, Wagner Law explains three main reasons of the national income to raise the government expenditure. Those reasons are: (i) when the country is on the industrialized period; (ii) when the economic growth causes an increasing demand of public services; and (iii) government contribution for a capital accumulation in which private sector would not satisfy. Rowley \& Tollison (1994) argued that Wagner Law would exist by comparing it with comparative advantage industries of the country which are under government authority. Hence, it can be said that the decreasing of comparative advantage will trigger the public expenditure - GDP ratio to be decreased (Peacock \& Scott, 2000).

We will elaborate the testing of Wagner Law in this study with other exogenous variables, such as population, total tax collected in post-reformation era for a deeper analysis. As Thomas Malthus has explained, population could be a problem for a country by comparing it with a food security. In the recent days, population growth problem correlates with the public services that government has to provide through government expenditure. Yet, this problem occurs in the developing countries oftentimes and burdening the government for the allocation of government expenditure. ${ }^{2}$

On the other side, total tax collected is one of government considerations on the determination of the government expenditure. While the people demand a higher public service level, government will satisfy it with a collected

\footnotetext{
${ }^{1}$ Keynesian shows that government expenditure is one of endogenous factor on economic growth through Keynesian Cross explanation (Mankiw, 2002). On the other hand, Wagner Law had proposed the opposite (economic growth raises the government expenditure) according to the fact that in industrialized period, public sector will actively play a key role which is driven by government expenditure (Mangkoesoebroto, 2001; Hussain, Iqbal, \& Siddiqi, 2010).

${ }^{2}$ Nevertheless, population is still considered as the agent of economy for economic growth. Kelly and Schmidt (1994) argued that a lower level of population growth would be more beneficial in the economy.
} 
tax from the people. In this case, collecting tax is affected by politics and jurisdiction system of the country, yet to mention the institutional system (Hussain, 2005). It can be totally understood since the government expenditure is also utilized for the public service obligation which cannot be provided by private sectors as the consequences of the market failure (Nicholson, 2002). Hence, regimes can bring a different impact to the government expenditure oftentimes, depend on the respective needs and allocations of the regime period (Kohler-Toglhofer \& Gnan, 2004; Carter \& Palmer, 2010; Bonan \& Lukkezen, 2013).

Indonesia is the fourth for the total population of the world and the determination of the government expenditure would always be a problem in the past (Population Reference Bureau, 2012). The population is predicted to increase from 241 millions in 2012 to be 309 millions in 2050, and burdening government expenditure therefore. Table 1 shows the GDP, tax collected, government expenditure and total population of Indonesia.

Table 1.GDP, Tax Collected, Government Expenditure and Total Population of Indonesia 2001 - 2011

\begin{tabular}{|c|c|c|c|c|}
\hline Year & $\begin{array}{l}\text { GDP } \\
\text { (IDR. } \\
\text { Billion) }\end{array}$ & $\begin{array}{l}\text { Tax } \\
\text { Collected } \\
\text { (IDR. } \\
\text { Billion) }\end{array}$ & $\begin{array}{l}\text { Government } \\
\text { Expenditure } \\
\text { (IDR. } \\
\text { Billion) }\end{array}$ & $\begin{array}{l}\text { Total } \\
\text { Population }\end{array}$ \\
\hline 2001 & $1,646,322$ & 222,846 & 378,822 & $216,203,499$ \\
\hline 2003 & $2,013,675$ & 241,808 & 376,505 & $221,839,235$ \\
\hline 2005 & $2,774,281$ & 346,834 & 505,276 & $227,303,175$ \\
\hline 2007 & $3,950,893$ & 491,666 & 737,853 & $232,461,746$ \\
\hline 2009 & $5,606,203$ & 641,380 & 956,379 & $237,414,493$ \\
\hline 2011 & $7,427,086$ & 873,735 & $1,290,423$ & $238,638,251$ \\
\hline
\end{tabular}

Source: International Financial Statistic (IFS) and World Bank

Aim of this study is to estimate the long-run and short-run relationship of the government expenditure and economic growth (Wagner Law), population and tax collected. Those variables will be elaborated with the regimes of Indonesia post-reformation era which takes on the following: (i) B. J. Habibie's regime; (ii) Abdurrahman Wakhid's regime; (iii) Megawati Soekarno Putri's regime; (iv) Susilo Bambang Yudhoyono I regime; and (v) Susilo Bambang Yudhoyono II regime. This estimation is to identify the existing of Wagner Law in Indonesia for the period of 1999 - 2011 and exogenous factors that affects the government expenditure. Moreover, regime variable will be used to identify whether volatility on the government expenditure is affected by regime transition or not.

\section{Literature Review}

Many studies have shown various results in testing the validity of Wagner Law. This theory was considered as a controversial after Keynesian Theory had released, so that many economists re-modelled other version of Wagner Law since 1960 (Demirbas, 1999; Halicioglu, 2003). According to Mangkoesoebroto (2001), Wagner Law is presumable as the 'organic theory of the state', of which government is considered as an independent

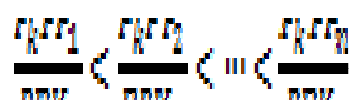

individual to the others. Furthermore, Wagner Law can be formulated as:

Where $P_{k} P P$ is government expenditure per capita and $P P K$ is national income per capita (GDP/total population). Peacock \& Wiseman (1961) proposed a theory for government expenditure according to tax collecting. That observation refers to the funding needs for the government on the war period. Those funding needs, mostly from tax, for war will reduce the investment and consumption of private sector (displacement effect). ${ }^{1}$ Moreover, the government still needs an additional funding by issuing both debt and obligation, yet to be paid in the future, which is known as inspection effect. Both effects (displacement effect and inspection effect) cause a shifting of

\footnotetext{
${ }^{1}$ The displacement effect causes the tax collected by government is shifted for allocation of war rather than for allocation of private sector needs (investment and consumption).
} 
the private's activities to be government activities, also known as concentration effect. Those three effects encourage the government activities to increase gradually and also increasing the government expenditure.

Arpaia \& Turin (2008) concluded that Wagner Law will occur if economy activity has an elastic demand toward government expenditure, and the growth of government expenditure will be higher than economic growth. According to Ram (1987), Wagner Law can be tested by estimating the government expenditure to GDP without lagged variable. Hence, it can be said that Wagner Law is a long-run equilibrium in the economy as whole, even though it is still possible to have an adjustment in the short-run. This fact is explained further by Kolluri, Panik, \& Wahab (2000) who showed the short-run adjustment in the case of Wagner Law in the G-7 countries for the period of $1960-1993$.

Test of the existing of Wagner Law in an economy can be performed by adding exogenous variables (Cheng and Lai, 1997; Ahsan, Kwan, \& Sahni, 1992; Hussain, Iqbal, \& Wahab, 2010). Nevertheless, the model should have a co-integration test among variables used. For example, Demirbas (1999) tested the six models of Wagner Law in Turkey, taking period of 1950 - 1990, by performing causality test of Granger (1969) and co-integration model of Engle-Granger. ${ }^{1}$ Demirbas (1999) got the result as Wagner Law did not matter in Turkey for the period taken, in which Bagdigen \& Centitas (2004) also had the same result for the period of 1965 - 2001 in Turkey.

On the other hand, Verma \& Arora (2010) proved that Wagner Law had occurred in India for the period of 1950 - 2008. The study showed that the first structural break on mid-liberalization period had caused an insignificant changing for the elasticity of government expenditure growth. But, the case of second structural break, the more intensive liberalization phase, showed a long-run equilibrium to prove the existing of Wagner Law. Also, Sideris (2006) proved that Wagner Law had matter in Greece for the period of 1833 - 1938 by performing Johansen's co-integration test and Granger causality test.

The exogenous variables that significantly affect government expenditure are population and tax collected (Peacock \& Wiseman, 1961; Mangkoesoebroto, 2001). According to Auerbach (2010), the government is highly possible to satisfy their target by optimizing its allocation of tax financing. It is also related to the population of which a country has to responsible for their welfare from the tax financing. Thus, many programs of the government, which is allocated on the government expenditure, will always depend on the total population of a country (Mehmood \& Sadiq, 2010; Bryant, et al., 2004; Fan, Hazell, \& Thorat, 1998). Primarily, those programs concerns on the people's welfare, such as poverty alleviation and health care.

The theory of government expenditure is regarded not to be apart from institutional role, despite non-institutional role has played its part as mentioned above. Since government activities keep raised, related to allocation of development planning, cause in volatility of government expenditure (Lamartina and Zaghini, 2008; Carmignani, Colombo, \& Tirelli, 2007; Priesmeier \& Koester, 2012; Akitoby et al., 2006). For example, external factors, such as exchange rate volatility, global oil price, and etc., can increase a vulnerability of domestic economy that has to be solved, either in short-run and long-run. Borcherding \& Lee (2004) mentioned that institutional role on the government expenditure is related to the policy of the regime's period, such as political appointments. The government expenditure tends to be increased as the consequence of political needs. ${ }^{2}$ Alm \& Embaye (2011) supported that statement as it was also happened in South Africa. The transition of post-Apartheid government had a significant difference on the government expenditure than pre-Apartheid government has had. ${ }^{3}$

\section{Methodology}

\subsection{Model Specification}

Aim of this study, as previously mentioned, is to identify the existing of Wagner Law in Indonesia by adding exogenous factors, such as total population and tax collected. Those variables will be elaborated with regime variable, generated by regimes in Indonesia post-reformation era. There are five regimes in the post-reformation era as we have explained above. This study takes period of 1999:Q1 - 2011:Q4 which is considered as transition era after the falling of new-order era. In addition, the regime variable will play role as ordered variable in the analysis and counted as 0 to 4 for the respective regime.

\footnotetext{
${ }^{1}$ The six models of Wagner Law on Demirbas (1999) is a development of basic model on the previous studies, following: a) Peacock \& Wiseman (1961); b) Goffman (1968); c) Mann (1980); d) Musgrave (1968); e) Gupta (1967); and f) Pryor (1969). ${ }^{2}$ Bagdigen \& Dokmen (2012) were concerning more on the institutional quality (corruption, bureaucracy, law and democracy) in determining the government expenditure. The higher level of institutional quality, the more effective government expenditure can be allocated because of lower transaction cost.

${ }^{3}$ Alm \& Embaye (2011) had found that the transition of South Africa government to post-Apartheid regime has been higher gradually than before.
} 
Firstly, we will specify an ARDL co-integration by performing Bound test for analysis of co-integration before identifying volatility on the government expenditure. This specification is regarded to be fit for the estimation since all variables are purely $I(0)$ or $I(1)$, to see whether there is a long-run relationship among variables used in this study. Pesaran, Shin, \& Smith (2001) and Pesaran \& Pesaran (1997) suggested the ARDL co-integration test by performing F-statistic for the respective joint significance in the long-run estimation of ARDL model. The ARDL Bound test for this study is also considered as the first stage model according to Wesseh \& Niu (2012) in

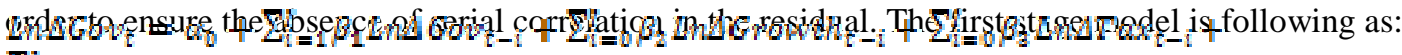

$\sum_{1=0}^{l} \beta_{1} \operatorname{Ln} \Delta$ Pop $_{t-1}+\delta_{1} \operatorname{LnGov}_{t-1}+\delta_{2} \operatorname{LnGrow}_{t-1}+\delta_{3} \operatorname{LnTax}_{t-1}+\delta_{d} \operatorname{LnPop}_{t-1}+\varepsilon_{t}$

Where Govt stands as government expenditure, Growth stands as economic growth, Tax stands as total tax collected by government, Pop stands as number of population and $\alpha_{0}$ is a drift component of the model. The Bound test for the analysis of long-run relationship is computed from coefficient values of lagged level variables of the first stage ARDL co-integration model (Ahmad et al., 2008). This test basically called Wald test of an unrestricted error correction model (UECM), following the null hypothesis of non-co-integrating relationship among variables: $\left(\mathrm{H}_{0}: \delta_{1}=\delta_{2}=\delta_{2}=\cdots=0\right)$.

At the same time, this co-integration model can also have an ARCH/GARCH component (Mantalos, Shukur, \& Sjolander, 2007; Wong, Li, \& Ling, 2005; Franses, Kofman, \& Moser, 1994). This process can be analysed by performing both heteroscedasticity test and ARCH-LM test for Equation 1. In addition, regime variable will be elaborated as a variance regressor to see whether regime transition affects the volatility on the government expenditure. The GARCH (p, q) model, following Haider \& Khan (2008), can be written as:

$\sigma_{t}^{2}=\pi+\theta \sum_{t=0}^{T} u_{t-1}^{2}+\varphi \sum_{t=0}^{T} \sigma_{t-1}^{2}+R_{t}$

Where $w_{t}^{2}$ is residual variance of Equation $1, \pi$ is constant value of variance, $u_{t}^{2}$ is an ARCH component, $w_{t}$ is GARCH component and $\boldsymbol{R}_{\boldsymbol{t}}$ is regime variable. The Equation 1 above, therefore, will be transformed into reduced form (second stage of ARDL co-integration) to get the long-run relationship for Wagner Law. This second stage can be obtained if and only if long-run relationship, by Wald test, would be existed. The reduced form of long-run model is following:

$\operatorname{LnGovt}_{t}=\varnothing_{1}+\emptyset_{2} \operatorname{LnGrowth}_{t}+\emptyset_{2} \operatorname{LnTax_{t}}+\varnothing_{4} \operatorname{LnPop_{t}}+u_{t}$

Parameters of the equation 2 are obtained from:

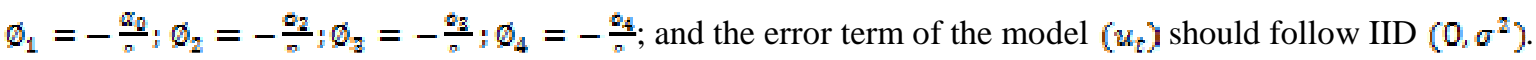

\subsection{Data}

This study uses data of government expenditure, economic growth, total population and tax collected for the period of first quarter of 1999 to the fourth quarter of 2011. The government expenditure, economic growth and tax collected are obtained from International Financial Statistic (IFS) and measured as real value using a base year of 2005 (in IDR), whereas the total population is obtained from World Bank Database. In addition, all variables will be turned into natural logarithmic form and counted in million.

Interpolation method will be performed on the total population data in order to obtain the quarterly data. Insukindro (1993) proposed a linear interpolation method to generate the quarterly data from yearly data, which is following as:

$Q_{n}=Y_{t-1}+\frac{a}{2}\left(Y_{t}-Y_{t-1}\right)$

Where $Q_{n}$ is quarterly data of quarter $n^{\text {th }}, Y_{t}$ is a yearly data of year $t^{\text {th }}$ and $\alpha$ is a parameter for respective quarter data. ${ }^{1}$ This interpolation method will yield a quarterly estimated data for total population.

The regime variable, on post-reformation era, is determined by period of respective regime. The B. J. Habibie's regime took period of May 1998 - October 1999, Abdurrahman Wahid's regime took period of October 1999 August 2001, Megawati Soekarno Putri's regime took period of August 2001 - October 2004, first regime of Susilo Bambang Yudhoyono took period of October 2004 - October 2009, and second regime of Susilo Bambang Yudhoyono has been taking period of October 2009 - current. ${ }^{2}$ Yet, the forming of ordered variable of regime is classified quarterly.

\footnotetext{
${ }^{1}$ Parameter's value for $1^{\text {st }}$ and $4^{\text {th }}$ quarter is 4.5 , whereas $2^{\text {nd }}$ and $3^{\text {rd }}$ take value of 1.5 .

${ }^{2}$ In this explanation, we show the president for the respective regime in post-reformation era as we have mentioned above.
} 


\section{Analysis}

\subsection{Unit Root Test}

We perform the ADF test, in this study, to identify the stationary level of each variable used for the ARDL cointegration model. The determination of optimum lag uses Akaike Information Criterion (AIC), which is test for un-restricted simple model. According to the ADF test, the $I(0)$ variables are economic growth, government expenditure and total population, while tax collected takes on the $I(1)$.

Table 2.Result for Unit Root Test (ADF Test)

\begin{tabular}{|c|c|c|c|c|}
\hline \multirow[b]{2}{*}{ Variable } & \multicolumn{2}{|l|}{ Level } & \multicolumn{2}{|c|}{ 1st Difference } \\
\hline & ADF-Stat & $\begin{array}{l}\text { Opt. } \\
\text { ADF } \\
\text { Model }\end{array}$ & $\begin{array}{l}\text { ADF- } \\
\text { Stat }\end{array}$ & $\begin{array}{l}\text { Opt. } \\
\text { ADF } \\
\text { Model }\end{array}$ \\
\hline $\begin{array}{l}\text { Ln } \\
\text { Growth }\end{array}$ & $-14.09189 *$ & Intercept & & \\
\hline Ln Gov & $\begin{array}{l}- \\
3.692774 * *\end{array}$ & $\begin{array}{l}\text { Intercept } \\
\& \text { Trend }\end{array}$ & & \\
\hline Ln Tax & -2.679446 & $\begin{array}{l}\text { Intercept } \\
\& \text { Trend }\end{array}$ & - $3.80834 *$ & Intercept \\
\hline Ln Pop & $\begin{array}{l}- \\
3.084391 * *\end{array}$ & Intercept & & \\
\hline
\end{tabular}

Note: $(*, * *)$ shows significant level of rejecting null hypothesis for ADF test by respective critical values of $1 \%$ and $5 \%$.

According to ADF test in Table 2, variables used in this study are varies in stationary level. Hence, the appropriate model to estimate the existing of Wagner Law in this study is ARDL co-integration. As we have mentioned before, identifying the long-run equilibrium will be employed firstly before identifying the short-run equilibrium.

\subsection{Result}

The main analysis of this study is to identifying the existing of Wagner Law in the long-run for Indonesia economy post-reformation era. Determination of long-run relationship is estimated by performing Bound test for Equation 1 above. Moreover, determination of lag optimum for the ARDL co-integration model will employ 'general to specific' method which can be seen on the Table 3. The ARDL co-integration model will determine the modelling of GARCH estimation for the case of volatility on government expenditure. Yet, determination of GARCH order will employ 'specific to general' method and elaborating the regime variable as variance regressor for GARCH estimation. 
Table 3.Estimation Result for ARDL Co-integration ${ }^{\mathrm{a}}$

\begin{tabular}{|c|c|c|c|}
\hline Variable $^{\mathrm{b}}$ & $\overline{\text { Coefficient }}^{\mathrm{c}}$ & & \\
\hline Constant & $\begin{array}{l}8.840465 * \\
(3.112523)\end{array}$ & $\begin{array}{l}\text { Adj. } \\
\text { squared }\end{array}$ & ${ }^{\mathrm{R}-} 0.902235$ \\
\hline $\begin{array}{l}\text { Ln } \Delta \text { Growth } \\
\text { (0) }\end{array}$ & $\begin{array}{l}2.404177 * \\
(0.822247)\end{array}$ & F-statistic & 22.41232 \\
\hline $\begin{array}{l}\text { Ln } \triangle \operatorname{Tax} \\
\text { (0) }\end{array}$ & $\begin{array}{l}0.355265 * * * \\
(0.181957)\end{array}$ & $\begin{array}{l}\mathrm{SE} \\
\text { regression }\end{array}$ & of $_{0.209779}$ \\
\hline $\begin{array}{l}\text { Ln } \triangle P o p \\
(1,2)\end{array}$ & $\begin{array}{l}-48.00663 * \\
(14.24155)\end{array}$ & SSR & 1.496243 \\
\hline Ln Gov $(-1)$ & $\begin{array}{c}-1.303263^{*} \\
(0.115197)\end{array}$ & AIC & -0.831439 \\
\hline Ln Growth(-1) & $\begin{array}{l}3.791496 * \\
(1.163964)\end{array}$ & SIC & -0.25231 \\
\hline $\operatorname{Ln} \operatorname{Tax}(-1)$ & $\begin{array}{l}0.576599 * \\
(0.198079)\end{array}$ & DW-statistic & 2.154352 \\
\hline Ln Pop $(-1)$ & $\begin{array}{l}0.363098 \\
(0.967534)\end{array}$ & & \\
\hline
\end{tabular}

Note: a) dependent variable: Ln $\triangle G o v$; b) parentheses on Variable column shows lag of regressors; c) parentheses on Coefficient column show standard error of regressors; $(*, * *, * * *)$ shows statistically significant for each variable on the respective significant level of $1 \%, 5 \%$ and $10 \%$.

Table 3 above shows the estimation of ARDL co-integration model for Equation 1. Co-integration test will be firstly employed to prove the long-run relationship of the ARDL co-integration model. According to F-statistic for Bound test, we find that the long-run relationship of variables used had occurred in Indonesia economy postreformation era (35.23701). Thus, the existing of Wagner Law is proven in this study as economic growth is statistically significant to affect the government expenditure. In addition, residual of ARDL co-integration model satisfies the normal distribution according to Jarque-Bera test with a critical value of 2.417216 .

Table 4.Estimation Result of GARCH $(1,2)^{\mathrm{a}}$

\begin{tabular}{|c|c|c|c|c|c|}
\hline$\overline{\text { Parameter }}$ & Constant & $u_{t-1}$ & $\omega_{t-1}$ & $\omega_{t-2}$ & Regime \\
\hline Coeff. & 0.004564 & $-0.265962 * * *$ & $0.6933332 *$ & $0.367429 * *$ & -0.000893 \\
\hline Std. Error & 0.00732 & 0.145132 & 0.066108 & 0.173205 & 0.002081 \\
\hline Z-statistic & 0.623591 & -1.832548 & 10.48793 & 2.121347 & -0.429184 \\
\hline
\end{tabular}

Note: a) dependent variable: residual variance $\sigma_{t}^{2} ;(*, * *, * * *)$ shows statistically significant for each variable on the respective significant level of $1 \%, 5 \%$ and $10 \%$.

Table 4 above shows that the most optimum variance equation of the ARDL co-integration model is GARCH (1, 2). It also explains that there is a volatility problem of the variance on the Wagner Law model in Indonesia economy for the period of 1999:Q1 - 2011:Q4. Moreover, economic growth coefficient, in the long-run, shows that change in economic growth by $1 \%$ will cause a change in the government expenditure by $2.92 \%$. On the 
other side, different regime of the government does not affect the volatility of the government expenditure according to the GARCH estimation.

We find that, in this study, Wagner Law had existed in Indonesia economy post reformation era by performing ARDL co-integration model. But, it is little bit different than the pure Wagner Law which only estimates the government expenditure to economic growth (Peacock and Wiseman, 1961). This result is in line with Ismal (2011) that proved the existence of Wagner Law in Indonesia for the period of 1980 - 2008 by elaborating other variables. ${ }^{1}$ This elaboration, however, should be considered in estimating Wagner Law since there are causality relationship between government expenditure and economic growth according to Granger causality test and Johansen test. Thus, it proves that Keynesian theory also did occur in Indonesia for the period taken in this study. Moreover, Johansen test concludes that the government expenditure and economic growth are co-integrated and have two possibilities of estimation. ${ }^{2}$

On the other side, the long-run relationship between government expenditure and economic growth can be estimated by performing ARDL model. The estimation result is provided on the Table 5 below.

Table 5.Estimation Result of ARDL Model for Wagner Law ${ }^{\mathrm{a}}$

\begin{tabular}{|c|c|c|c|c|}
\hline \multirow{2}{*}{$\begin{array}{l}\text { Variable } \\
\text { Constant }\end{array}$} & \multicolumn{4}{|l|}{ Coefficient $^{\mathrm{b}}$} \\
\hline & $3.28612 *$ & $(0.82612)$ & Adj. R-squared & 0.621085 \\
\hline $\operatorname{Ln} \operatorname{Gov}(-4)$ & $0.527624 *$ & $(0.118624)$ & S.E. of regression & 0.234788 \\
\hline Ln Growth & $3.683151^{*}$ & (1.171989) & SSR & 2.370395 \\
\hline Ln Growth(-1) & $2.563999 *$ & $(0.916155$ & F-statistic & 20.25963 \\
\hline \multirow[t]{2}{*}{ Ln Growth(-2) } & $2.621431^{* *}$ & (1.132003) & AIC & 0.038066 \\
\hline & & & SIC & 0.232983 \\
\hline
\end{tabular}

Note: a) dependent variable: Ln Gov; b) parentheses on Coefficient column show the standard error of regressors; $(*, * *)$ shows statistically significant of each variable on the respective significant level of level $1 \%$ and $5 \%$.

The ARDL model above is considered as modified Wagner Law by adding lagged endogenous variable. This result also proves the existence of Wagner Law in Indonesia for the period of 1999:Q1 - 2011:Q4. It is known, from the estimation, that the government expenditure in the previous year affects the determination of government expenditure. Also, the first and second of the previous quarter of economic growth does affect the determination of government expenditure. The ARDL model above satisfies classical assumption of OLS according to Jarque-Bera test (2.287485), Breusch-Godfrey Serial Correlation LM test (1.82044), White heteroscedasticity test $(0.889473)$ and RAMSEY-Reset test (0.080914). But, that model shows an un-stability on the period of $2002-2007$ according to CUSUM-squares.

Those two models (ARDL co-integration and ARDL) generally show the existence of Wagner Law for the period of 1999:Q1 - 2011:Q4. Although we generate a modified Wagner Law, the model specification in this study is aimed to get the robust estimation. In addition, we find that tax collected, on the Table 3 , affects the determination of government expenditure. It is in line with Peacock and Wiseman (1961) of that the government will consider tax collected, which is considered as government revenue, to determine the government expenditure and its appropriate allocation.

\section{Conclusion}

This study provides analysis of long-relationship between government expenditure and economic growth in Indonesia post-reformation era, which is popularly known as Wagner Law. Nevertheless, we modify the pure Wagner Law by adding exogenous variables to the model those are total population and tax collected. Many previous studies used the modified model in estimating Wagner Law in order to provide the best explanation of

\footnotetext{
${ }^{1}$ Ismal (2011) elaborated several variables in estimating Wagner Law, such as government debt payment, oil export and total import.

${ }^{2}$ See Appendix for the detail explanation of Granger causality test and Johansen co-integration test.
} 
Wagner Law in an economy (Hussain, Iqbal, \& Siddiqi, 2010; Akitoby et al., 2006; Ismal, 2011; Wijayanti, 2008).

Estimation results in this study show that Wagner Law had occurred in Indonesia for the period of 1999:Q1 2011:Q4, concerning volatility problem on the government expenditure. It is generated by two estimation models, ARDL co-integration and ARDL, which prove the long-run relationship between the government expenditure and economic growth by performing Bound test. On the other hand, the regime transition did not affect to volatility on the government expenditure. This result is based on the estimation of GARCH $(1,2)$ that accommodating regime variable bas variance regressor.

In addition, ARDL model is employed in order to test the both existing of Wagner Law and lag on the determination of government expenditure. We find that Wagner Law had also occurred in Indonesia economy post-reformation era as ARDL co-integration model states above. Lag of the government expenditure shows that the current government expenditure is based on the previous year. It is in line with Mangkoesoebroto (2001) in which the determination of the government expenditure is always based on how it had been the previous year. In addition, this study is in line with Peacock \& Wiseman (1961) as the lag of economic growth is statistically significant to affect the government expenditure. The lag of economic growth could be base of economy capacity and the development stage of a country in order to determine the effective allocation of funding.

Another necessary concern on this study is the possibility of existing of the Keynesian theory. According to Granger causality test and Johansen test, it is known that there are two possibilities of estimation for the long-run relationship between government expenditure and economic growth. Ismal (2011) showed the similar result and concluded that the application of both theory, Wagner Law and Keynesian, will depend on the discretion of fiscal policy. Since the discretion of fiscal policy should consider the economy condition, both in domestic and global, those two theories are likely to exist at the same time.

\section{References}

Ahsan, S. M. Kwan, A. C. C., \& Sahni, B. S. (1992). Public Expenditure and National Income Causality: Further Evidence on the Role of Omitted Variables. Southern Economic Journal, Vol. 3, January 1992: 621-632.

Alm, J. \& Embaye, A. (2011). Explaining the Growth of Government Spending in South Africa. Tulane Economics Working Paper Series, 1105.

Ahmad, A. H. et al. (2008). Sovereign Credit Ratings and Macroeconomic Variables: An Empirical Analysis on Dynamic Linkages in Malaysia using Bound Testing Approach. The IUP Journal of Applied Economics, Vol. VII, Issue 6: pp. 29-39.

Akitoby, B. et al. (2006). Public Spending, Voracity, and Wagner's Law in Developing Countries. European Journal of Political Economy 22: pp. 908 - 924.

Arpaia, A. \& Turrini, A. (2008). Government Expenditure and Economic Growth in the EU: Long-Run Tendencies and Short-Term Adjustment. Economic Papers of Economic and Monetary Union (EMU), 300.

Auerbach, A. J. (2010). Public Finance in Practice and Theory. CESifo Economic Studies, Oxford University Press, Vol. 56(1): 1-20.

Nicholson, W. (2002). Microeconomic Theory: Basic Principles and Extensions: $8^{\text {th }}$ Edition. SouthWestern/Thomson Learning.

Bagdigen, M. \& Çentitas, H. (2004) Causality between Public Expenditure and Economic Growth: The Turkish Case. Journal of Economics and Social Research, Vol. 6: pp. 53-72.

Bagdigen, M. \& Dokmen, G. (2012) Effect of Institutional Quality on the Size of State: A Dynamic Panel Data Study. Journal of Economic and Social Research, Vol. 14(1): pp. 27-56.

Bonam, D. \& Lukkezen, J. (2013) Government Spending Shock, Sovereign Risk and the Exchange Rate Regime," paper presented at the 'TKI Seminar Series 2013', Universiteit Utrecht.

Bryant, J. et al. (2004) Population Ageing and Government Health Expenditures in New Zealand, 1951 - 2051. New Zealand Treasury Working Paper 04/14.

Carmignani, F., Colombo, E., \& Tirelli, P. (2007) Public Expenditure and Growth Volatility: Do Globalisation and Institution Matter? Working Paper Series, No. 116/2007, Department of Economics, University of Milan-Bicocca. 
Carter, J. \& Palmer, G. (2010) Keeping the Schools Open While the Troops are Away: Regime Type, Interstate War and Government Spending," paper presented at the annual meetings of the 'International Studies Association' (2008) and 'Network of European Peace Scientist (2008)'.

Cheng, B. S. \& Lai, T. W. (1997) Government Expenditures and Economic Growth in South Korea: A VAR Approach. Journal of Economic Development, Vol. 22(1).

Demirbas, S. (1999) Co-integration Analysis-Causality Testing and Wagner's Law the Case of Turkey, 19501990. Discussion Papers in Economics 99/3, Department of Economics, University of Leicester.

Fan, S., Hazell, P. \& Thorat, S. (1998) Government Spending, Growth and Poverty: An Analysis of Interlinkages in Rural India. Environment and Production Technology Division (EPTD) Discussion Paper No. 33.

Franses, P. H., Kofman, P. \& Moser, J. (1994) GARCH Effects on a Test of Cointegration. Review of Quantitative Finance and Accounting, Vol. 4: pp. 19-26.

Haider, A. \& Khan, S. U. (2007) Does Volatility in Government Borrowing Leads to Higher Inflation? Evidence from Pakistan, MPRA Paper No. 17008.

Halicioglu, F. (2003) Testing Wagner's Law for Turkey, 1960-2000: Review of Middle East Economics and Finance. Taylor and Francis Journals, Vol. 1(2), August: 129-140.

Hussain, M. H. (2005) On the Casual Relationship between Government Expenditure and Tax Revenue in Pakistan. The Lahore Journal of Economics, Vol. 9, No.2.

Hussain, T., Iqbal, A., \& Siddiqi, M. W. (2010) Growth, Population, Exports, and Wagner's Law: A Case Study of Pakistan (1972-2007). International Journal of Human and Social Science 5: 5.

Ismal, R. (2011) Assessing Economic Growth and Fiscal Policy in Indonesia. Journal of Economics and Business, Vol. XIV, No. 1: pp. 53-71.

Kelly, A. C. \& Schmidt, R. M. (1994) Population and Income Change: Recent Evidence. World Bank Paper, No. 249, Washington D. C.

Kohler-Toglhofer, W. \& Gnan, E. (2004) The Impact of Different Fiscal Policy Regimes on Public Debt Dynamics. Studie Paper Series, Nr. 04/04.

Kolluri, B. R., Panik, M. J., \& Wahab, S. (2000) Government Expenditure and Economic Growth: Evidence from G7 Countries. Applied Economics, 32: 1059-1068.

Lamartina, S. \& Zaghini, A. (2008) Increasing Public Expenditure: Wagner's Law in OECD Countries. CFS Working Paper Series 2008/13, Center for Financial Studies.

Mangkoesoebroto, G. (2001) Ekonomi Publik: Edisi Ketiga. Balai Penerbitan Fakultas Ekonomi (BPFE) UGM, Yogyakarta.

Mantalos, P., Shukur, G. \& Sjolander, P. (2007) An Examination of the Robustness of the Vector Autoregressive Granger-Causality Test in the Presence of GARCH and Variance Shifts. International Review of Business Research Papers, Vol. 3/No. 5: pp. 280 - 296.

Mehmood, R. \& Sadiq, S. (2010) The Relationship between Government Expenditure and Poverty: A Cointegration Analysis. Romanian Journal of Fiscal Policy, Vol. 1, Issue 1: pp. 29-37.

Nicholson, W. (2002) Microeconomic Theory: Basic Principles and Extensions: $8^{\text {th }}$ Edition. SouthWestern/Thomson Learning.

Peacock, A. \& Scott, A. (2000) The Curious Attraction of Wagner's Law. Public Choice, Vol. 102: pp. 1-17.

Peacock, A. T. \& Wiseman, J. (1961) The Growth of Public Expenditure in the United Kingdom. NBER Book Series, UMI Publisher.

Pesaran, M. H., Shin, Y., \& Smith, R. J. (2001) Bound Testing Approaches to the Analysis of Level Relationship. Journal of Applied Econometrics, Vol. 16(3): 289-326.

Pesaran, M. H. \& B. Pesaran, (1997) Working with Microfit 4.0: Interactive Econometric Analysis. Oxford University Press: Oxford.

Priesmeier, C. \& Koester, G. B. (2012) Does Wagner's Law Ruin the Sustainability of German Public Finances? Discussion Paper Series, No. 08/2012, Deutsche Bundesbank.

Ram, R. (1987) Wagner's Hypotheses in Time-Series and Cross-Section Perspective: Evidence from Real Data for 115 Countries. The Review of Economics and Statistics, 69(1): pp. 194-204. 
Rowley, C. K. \& Tollison, R. D. (1994) Peacock and Wiseman on the Growth of Public Expenditure. Public Choice, Vol. 78, pp. 125-128.

Sideris, D. (2006) Wagner's Law in 19th Century Greece: A Co-integration and Causality Analysis. Applied Economics, 25: pp. 125-134.

Verma S. \& Arora, R. (2010) Does the Indian Economy Support Wagner's Law? An Econometric Analysis. Eurasian Journal of Business and Economics 3:5, 77-91.

Wesseh, P. K. \& Niu, L. (2012) The Impact of Exchange Rate Volatility on Trade Flows: New Evidence from South Africa. International Review of Business Research Papers, Vol. 8, No. 1: pp. 140-165.

Wijayanti, I. Y. (2008) Analisis Kausalitas antara Pengeluaran Pemerintah dan Pertumbuhan Ekonomi di Indonesia Tahun 1970-2005. undergraduate thesis at Universitas Gadjah Mada, Department of Economics and Business.

Wong, H., Li, W. K., \& Ling, S. (2005) Joint Modeling of Cointegration and Conditional Heteroscedasticity with Applications. Annual Institute of Statistical Mathematics, Vol. 57/No. 1: pp. 83-103. 
The IISTE is a pioneer in the Open-Access hosting service and academic event management. The aim of the firm is Accelerating Global Knowledge Sharing.

More information about the firm can be found on the homepage:

http://www.iiste.org

\section{CALL FOR JOURNAL PAPERS}

There are more than 30 peer-reviewed academic journals hosted under the hosting platform.

Prospective authors of journals can find the submission instruction on the following page: http://www.iiste.org/journals/ All the journals articles are available online to the readers all over the world without financial, legal, or technical barriers other than those inseparable from gaining access to the internet itself. Paper version of the journals is also available upon request of readers and authors.

\section{MORE RESOURCES}

Book publication information: http://www.iiste.org/book/

Recent conferences: http://www.iiste.org/conference/

\section{IISTE Knowledge Sharing Partners}

EBSCO, Index Copernicus, Ulrich's Periodicals Directory, JournalTOCS, PKP Open Archives Harvester, Bielefeld Academic Search Engine, Elektronische Zeitschriftenbibliothek EZB, Open J-Gate, OCLC WorldCat, Universe Digtial Library, NewJour, Google Scholar

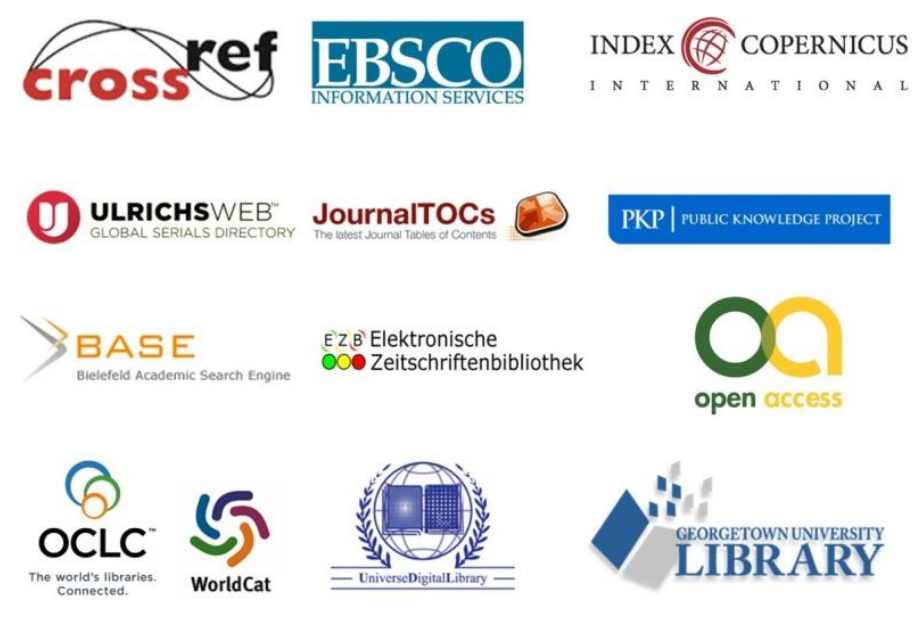

